\title{
Trophic dynamics of two sympatric mysid species in an estuarine transition zone
}

\author{
Gesche Winkler*, Christine Martineau, Julian J. Dodson, Warwick F. Vincent, \\ Ladd E. Johnson
}

Québec-Océan, Département de biologie, Université Laval, Ste-Foy, Quebec G1K 7P4, Canada

\begin{abstract}
The feeding ecology of 2 sympatric mysid species within the food web of the St. Lawrence Middle Estuary was studied to determine their trophic position and potential mechanisms of coexistence. These abundant predators were clearly distinguished by differences in foraging behaviour. In feeding experiments involving multi-prey assemblages, predation and ingestion rates of Mysis stenolepis were greater than for Neomysis americana, except for small prey. M. stenolepis showed highest predation rates on and preference for Eurytemora affinis nauplii and copepodites, and did not feed on the most abundant prey, the veliger stage of the zebra mussel Dreissena polymorpha. In contrast, $N$. americana showed highest predation rates on and preference for small prey species such as rotifers, nauplii and veligers. When densities of preferred prey declined in the second half of the experiment, both mysid species showed a shift in predation towards the less preferred prey. M. stenolepis switched to filter feeding, with higher predation rates on veligers, whereas $N$. americana increased predation on small $E$. affinis copepodites. Stable isotope analysis and feeding experiments suggested 3 trophic levels in the food web, with a high degree of omnivory. The $\delta^{13} \mathrm{C}$ values for the 2 mysid species were similar and supported by the same carbon source, mostly of autochthonous origin. However, their $\delta^{15} \mathrm{~N}$ differed significantly by $2.2 \%$, indicating that the composition of their diet differed in terms of ingested and assimilated food items. These results suggest that co-existence of the sympatric mysid populations is achieved by reduced competition due to foodniche partitioning. Flexibility in their foraging behaviour allowed mysids to exploit multiple prey groups that undergo temporal and spatial fluctuations in the highly dynamic estuarine transition zone of the St. Lawrence Middle Estuary.
\end{abstract}

KEY WORDS: Mysis stenolepis - Neomysis americana $\cdot$ Feeding experiments $\cdot$ Zooplankton assemblage $\cdot$ Stable isotopes

Resale or republication not permitted without written consent of the publisher

\section{INTRODUCTION}

Mysids are a major component of estuarine and coastal zooplankton communities in terms of both abundance and biomass. Due to their importance as a food source for fishes, there are many studies of their distribution and population dynamics (for review see Tattersall \& Tattersall 1951, Mauchline 1980), but their importance in trophic dynamics is still not well understood. Mysids are generally considered to be omnivores, and adjust their foraging behaviour according to food availability (Mauchline 1980). Their potential impact on zooplankton community structure has been well studied in lakes, where mysids have been introduced to improve salmonid fisheries, resulting in major declines in the abundance of cladocerans and, at times, copepods (Morgan 1981, Langeland 1988). In estuaries, high mortality rates of copepods have been observed, due to the predation pressure of mysids (Johnston \& Lasenby 1981, Jerling \& Wooldridge 1995).

Two sympatric mysid species, Mysis stenolepis and Neomysis americana, occur in many estuaries of northeastern North America, including the St. Lawrence 
Estuary. The estuarine transition zone (ETZ) of the St. Lawrence Middle Estuary is a highly productive region for both mysid species. The ETZ is characterised by sharp gradients in salinity, temperature and nutrient content, and hydrodynamic forces create strong estuarine re-circulation. This acts as a retention mechanism for inorganic and organic matter, resulting in high turbidity and high biomass of primary producers, herbivores and planktivores (Frenette et al. 1995, Vincent et al. 1996, Winkler et al. 2003). The zooplankton community in the transition zone is composed of 3 distinct assemblages that are mainly determined by average salinity and the degree of water column stratification: (1) a tidal-freshwater assemblage in waters of salinities < 1.6 psu, characterised by high abundances of veligers of the bivalve invader Dreissena polymorpha, rotifers, the amphipod Gammarus tigrinus and cladocerans (mostly Bosmina longirostris); (2) an estuarine assemblage in weakly stratified waters of salinities between 0.5 and 6 psu, characterised by abundance peaks of the calanoid copepod Eurytemora affinis and 2 mysid species $M$. stenolepis and $N$. americana; and (3) a euryhaline marine assemblage composed of high abundances of marine copepods such as Calanus spp. and Acartia spp. (Laprise \& Dodson 1994, Winkler et al. 2003, 2005). High abundances of $M$. stenolepis and $N$. americana are found during the summer months when zooplankton standing stock is also high (G. Winkler, L. E. Johnson, J. J. Dodson unpubl. data). Little is known about the trophic dynamics, niche overlap and potential competition of these sympatric species in the food web of the ETZ.

The feeding ecology of mysids has traditionally been assessed by the analysis of stomach contents (Grossnickle 1979, Fockedey \& Mees 1999, Viherluoto et al. 2000). Stomach content analysis of both mysid species Mysis stenolepis and Neomysis americana in the ETZ revealed a diverse diet of calanoid and harpacticoid copepods, cladocerans, rotifers, diatoms and pollen, suggesting omnivorous foraging behaviour (Winkler et al. 2003). Feeding rates, preferences and selection of these food items are not known. Elsewhere, N. americana has been shown in experiments to prey on several marine copepods such as Acartia tonsa and Centropages spp., although gut content analyses revealed a dominance of detritus (Fulton 1982). This approach has its limitations: stomach content analysis shows ingested food and the relative proportion of each item ingested, but underestimates easily digested items, such as soft-bodied rotifers, and no estimates of ingestion rates are possible. Ingestion rates can, however, be assessed by feeding experiments designed to define functional responses to predator size, prey size and prey density (Webb et al. 1987, Wooldridge \& Webb 1988, Winkler \& Greve 2004), but these studies typi- cally involve 1 or 2 prey (Fulton 1982, Gorokhova \& Hansson 1997, Viitasalo \& Rautio 1998, Viherluoto \& Viitasalo 2001a), which severely limits interpretation within a complex food web. Interactions among different prey types as a function of their abundance, size and escape behaviour may play an important role in determining the predation rate on each individual species in their natural environment. For example, predation rates on copepod Acartia tonsa by Praunus flexuosus were reduced when a second copepod prey, Eurytemora affinis, was present (Viitasalo \& Rautio 1998).

Short-term experiments can only provide information on potential trophic interactions. Fortunately, stable isotope analysis can provide integrated estimates of carbon source trophic position. This technique gives a time-integrated view of the food assimilated by an organism, accounting for complex food web interactions such as omnivory (Cabana \& Rasmussen 1996). Stable carbon isotope ratios $\left(\delta^{13} C\right)$ reveal the nature of the carbon source ingested, as the signature increases only slightly in the consumer during assimilation of food sources (Peterson \& Fry 1987, France \& Peter 1997, Johannsson et al. 2001). However, the stable nitrogen isotope ratios $\left(\delta^{15} \mathrm{~N}\right)$ can be used to identify trophic position (Cabana \& Rasmussen 1996), as the signature of a consumer is typically enriched by $3.4( \pm 1) \%$ relative to its food source (Minigawa \& Wada 1984). Recent work on the diet of Mysis relicta with stable isotope signatures in combination with stomach content analysis showed more informative results (Johannsson et al. 2001) than each approach by itself. Stomach content analysis identified diatoms as an important prey item, but only with stable isotope analysis were those authors able to show that diatoms accounted for $50 \%$ of the energy intake of the mysids.

The purpose of this study was to determine the trophic position of the mysid species Neomysis americana and Mysis stenolepis in the food web of the estuarine transition zone of the St. Lawrence Estuary. We also examined the potential for competitive interactions between these 2 species, leading to resource partitioning. To address these objectives, we carried out laboratory feeding experiments with naturally occurring zooplankton assemblages to include the potential of interference among different prey species, while quantitatively evaluating predation rates, prey preference and prey selection by $N$. americana and $M$. stenolepis. In addition, we compared the experimental results with the stable isotope signatures of both mysid species and their potential mesozooplankton prey in the ETZ to assess quantitatively the role of mysid species in energy transfer and their impact on prey communities. 


\section{MATERIALS AND METHODS}

Predation experiments. Prey selection and diet overlap of Mysis stenolepis and Neomysis americana were investigated with different experiments simulating various prey-assemblage compositions encountered by mysids in their natural environment (Table 1). $M$. stenolepis and $N$. americana were collected in the St. Lawrence Middle Estuary from a dock at L'Islet (Quebec) in July and August $20011 \mathrm{~d}$ prior to each experiment. Mysids were collected at high tide with a plankton net $(50 \mathrm{~cm}$ diameter, $250 \mu \mathrm{m}$ mesh size). After collection, mysids were immediately brought into a $20^{\circ} \mathrm{C}$ temperature-controlled laboratory situated at Berthier-sur-Mer, where they were transferred into filtered river water 12 to $24 \mathrm{~h}$ before the experiments. Zooplankton were collected prior to the experiments from the beach at Berthier-sur-Mer using a plankton net (50 cm diameter, $63 \mu \mathrm{m}$ mesh size). Several zooplankton hauls were made slowly over a distance of $10 \mathrm{~m}$ to minimise damage to the organisms. The zooplankton sample was brought into the laboratory within 15 min after collection. We used sub-samples of the zooplankton sample to calculate prey concentrations that we introduced into the experiments. We identified the following taxa: rotifers, the zebra mussel Dreissena polymorpha (veligers), the calanoid copepod Eurytemora affinis (divided into 2 classes: Copepodites I to IV and Copepodites V and VI), copepod nauplii (mostly E. affinis), cyclopoid copepods (mainly Cyclops sp.), harpacticoid copepods (mainly Ectinosoma curticorne) and the cladoceran Bosmina longirostris.

Three predation experiments (denoted as Expt 1, Expt 2 and Expt 3) were conducted in experimental units of 16 tanks each containing $30 \mathrm{l}$ filtered estuarine water and kept under dimmed room lighting. Environmental conditions varied little among tanks and represented similar conditions to those mysids encountered in their natural habitat in July and August 2001 (mean $\pm \mathrm{SD}$ water temperature $=20.3 \pm 0.5^{\circ} \mathrm{C}[$ Expt 1] and $19.6 \pm 0.3^{\circ} \mathrm{C}$ [Expt 2 and Expt 3], mean \pm SD salinity $=$ $1.9 \pm 0.02$ psu [Expt 1 and Expt 2] and 0.6 psu [Expt 3], turbidity $=5$ to 9 NTU [nephelometer turbidity units]). All experiments started in the morning and were carried out over $12 \mathrm{~h}$. Sub-samples (3) were taken from each

Table 1. Neomysis americana and Mysis stenolepis. Feeding experiments with naturally occurring zooplankton assemblages. Means $\left( \pm \mathrm{SD}\right.$ ) of (a) physical parameters and (b) prey parameters at the start $\left(t_{0}\right)$ and over the $12 \mathrm{~h}$ period of the 3 experiments, for each predator treatment. Treatments were replicated in each experiment: 6 tanks containing N. americana (N.a.) at a density of 2.5 mysid l-1, 6 tanks containing M. stenolepsis (M.s.) at a density of 1.0 mysid $\mathrm{l}^{-1}$, and 4 control tanks containing no mysid predators. Prey taxa and groups offered were veligers (Dreissena polymorpha), nauplii, rotifers, Eurytemora affinis (E.a.) Stages I to IV and V to VI, Bosmina longirostris, and cyclopoid and harpacticoid copepods

\begin{tabular}{|c|c|c|c|c|c|c|}
\hline Parameter & \multicolumn{2}{|c|}{$\begin{array}{c}\text { Expt } 1 \\
\text { (31 July 2001) }\end{array}$} & \multicolumn{2}{|c|}{$\begin{array}{c}\text { Expt } 2 \\
\text { (2 August 2001) }\end{array}$} & \multicolumn{2}{|c|}{$\begin{array}{c}\text { Expt } 3 \\
\text { (7 August 2001) }\end{array}$} \\
\hline \multicolumn{7}{|l|}{ (a) Physical } \\
\hline Temperature $\left({ }^{\circ} \mathrm{C}\right)$ & \multicolumn{2}{|c|}{$20.3( \pm 0.5)$} & \multicolumn{2}{|c|}{$19.6( \pm 0.3)$} & \multicolumn{2}{|c|}{$19.6( \pm 0.3)$} \\
\hline Salinity (psu) & \multicolumn{2}{|c|}{$1.9( \pm 0.2)$} & \multicolumn{2}{|c|}{$1.9( \pm 0.2)$} & \multicolumn{2}{|c|}{$0.6( \pm 0.1)$} \\
\hline Turbidity (NTU) & \multicolumn{2}{|c|}{$8.7( \pm 2.0)$} & \multicolumn{2}{|c|}{$4.8( \pm 1.2)$} & \multicolumn{2}{|c|}{$5.3( \pm 1.6)$} \\
\hline \multicolumn{7}{|l|}{ (b) Prey } \\
\hline No. of taxa/groups & \multirow{2}{*}{\multicolumn{2}{|c|}{$\begin{array}{c}4 \\
83(+11)\end{array}$}} & \multicolumn{2}{|c|}{8} & \multicolumn{2}{|l|}{7} \\
\hline Biomass at $t_{0}\left(\mu \mathrm{g}\right.$ DW $\left.\mathrm{l}^{-1}\right)$ & & & \multicolumn{2}{|c|}{$715( \pm 104)$} & \multicolumn{2}{|c|}{$623( \pm 87)$} \\
\hline \multirow[t]{3}{*}{ Density at $t_{0}$ (ind. $\mathrm{l}^{-1}$ ) } & \multicolumn{2}{|c|}{$517( \pm 59)$} & \multicolumn{2}{|c|}{$1105( \pm 97)$} & \multicolumn{2}{|c|}{$1105( \pm 97)$} \\
\hline & \multicolumn{4}{|c|}{ Predator treatment } & \multirow[b]{2}{*}{ N.a. } & \multirow[b]{2}{*}{ M.s. } \\
\hline & N.a. & M.s. & N.a. & M.s. & & \\
\hline \multirow[t]{2}{*}{ Density over $12 \mathrm{~h}$ (ind. $\mathrm{l}^{-1}$ ) } & $253( \pm 26)$ & $454( \pm 35)$ & $374( \pm 44)$ & $824( \pm 88)$ & $669( \pm 41)$ & $945( \pm 75)$ \\
\hline & & & \multicolumn{2}{|c|}{ Proportion in prey field (\%) at $t_{0}$} & \multirow[b]{2}{*}{ Density } & \multirow[b]{2}{*}{ Biomass } \\
\hline Taxon/group & Density & Biomass & Density & Biomass & & \\
\hline Veligers & 62.6 & 31.7 & 67.65 & 13.0 & 52.38 & 11.5 \\
\hline Nauplii & 21.6 & 46.5 & 7.48 & 2.8 & 25.46 & 11.0 \\
\hline Rotifers & 15.5 & 17.6 & 11.52 & 3.1 & 9.78 & 2.8 \\
\hline E.a. I-IV & - & - & 8.42 & 31.9 & 10.66 & 49.5 \\
\hline E.a. V-VI & - & - & 2.58 & 32.1 & 1.14 & 19.9 \\
\hline B. longirostris & - & - & 0.49 & 2.4 & 0.10 & 0.6 \\
\hline Cyclopoids & 0.2 & 4.2 & 1.72 & 14.1 & 0.50 & 4.7 \\
\hline Harpacticoids & - & - & 0.14 & 0.5 & - & - \\
\hline
\end{tabular}


tank, using jars of precise volumes (500 and $1000 \mathrm{ml})$, at the beginning of the experiment $\left(t_{0 ;} 500 \mathrm{ml}\right)$, after $6 \mathrm{~h}$ in the middle of the experiment $\left(t_{1 ;} ; 00 \mathrm{ml}\right)$ and after $12 \mathrm{~h}$ at the end of the experiment $\left(t_{2} ; 1000 \mathrm{ml}\right)$ to determine changes in zooplankton prey concentration in experimental and control tanks. Predator densities were adjusted to account for differences in mysid size. Predator densities were 1 mysid $\mathrm{l}^{-1}$ for Mysis stenolepis (19 to $23 \mathrm{~mm}$ ) and 2.5 mysid $\mathrm{l}^{-1}$ for Neomysis americana $(6$ to $8 \mathrm{~mm})$. Each experiment involved 3 treatments: (1) M. stenolepis as predator (6 tanks), (2) $N$. americana as predator ( 6 tanks) and (3) control treatment without predators (4 tanks) (Table 1). Each experimental tank (rectangular: $50 \mathrm{~cm} \times 30 \mathrm{~cm} \times 35 \mathrm{~cm}$ ) was equipped with a plastic paddle at the bottom of the tank. All 16 paddles were connected to a metal frame suspended above the tanks. The frame and attached paddles were slowly displaced to and fro by an electric motor so as to gently agitate the bottom waters and suspend organisms and particles in the water column.

In Expt 1 (31 July 2001, 4 prey taxa) we tested common summer densities of zooplankton in the ETZ of $517 \pm 59$ ind. $\mathrm{l}^{-1}\left(83 \pm 11 \mu \mathrm{g}\right.$ dry weight $\left.[\mathrm{DW}] \mathrm{l}^{-1}\right)$. The initial prey field mostly consisted of small prey items: veligers $(63 \%)$, nauplii $(22 \%)$ and rotifers $(16 \%)$. In terms of biomass, veligers, nauplii and rotifers again dominated with only $4 \%$ of biomass composed of cyclopoid copepods (Table 1).

Double prey density was offered in Expt 2 (2 August 2001, 8 prey taxa) of $1105 \pm 97$ ind. $\mathrm{l}^{-1}$ and a biomass of $715 \pm 104 \mu \mathrm{g} \mathrm{DW}^{-1}$. The prey field again consisted of a high proportion of small prey: $68 \%$ veligers, $12 \%$ rotifer and $7 \%$ nauplii plus $13 \%$ larger prey, Eurytemora affinis (divided into 2 classes: Copepodites I to IV and Copepodites V and VI), cyclopoid and harpacticoid copepods and Bosmina longirostris (Table 1). In terms of biomass, $32 \%$ was contributed by each of the 2 classes of E. affinis, $14 \%$ by cyclopoid copepods, $13 \%$ by veligers and $9 \%$ by the other prey taxa, rotifers, $B$. longirostris and harpacticoid copepods (Table 1).

Expt 3 ( 7 August 2001, 7 prey taxa) started with the same prey density of $1105 \pm 97$ ind. $\mathrm{l}^{-1}$ and a slightly lower biomass of $623 \pm 87 \mu \mathrm{g} \mathrm{DW} \mathrm{l^{-1 }}$ than Expt 2. No harpacticoid copepods were available in this experiment. The prey field also differed in prey composition from Expt 2, with a lower proportion of veligers (52\%) and a higher proportion of nauplii $(25 \%)$ (Table 1 ). Eurytemora affinis dominated the biomass, which was distributed as $50 \%$ Copepodites I to IV and $20 \%$ Copepodites V and VI. Veligers and nauplii each contributed $11 \%$ of the prey biomass, and the other prey taxa, rotifers, B. longirostris and cyclopoid copepods accounted for the remaining $9 \%$ (Table 1).

Isotopic analysis. Details on field sampling and isotopic analysis are described in Martineau et al.
(2004) and Barnard et al. (2006). Briefly, zooplankton samples for isotopic analysis were obtained by horizontal trawls during 3 cruises in summer 2001 (10 July, 20 July and 1 August) at 3 stations across the ETZ (northern, middle and southern channel) using a 500 and $64 \mu \mathrm{m}$ net for mysids and other zooplankton species, respectively. The samples were preserved on ice until laboratory processing. They were then sorted by hand, washed with deionised water, freeze-dried, ground with an agate mortar and pestle and kept in a desiccator until mass spectrometry analysis. All isotopic analyses were carried out with an elemental analyser NC 2500 (CE instruments), coupled with an isotopic ratio mass spectrometer (VG Prism III, Fisons Instruments) at the Delta-Lab, Commission Géologique du Canada, Quebec. Stable isotope ratios were expressed as parts per thousand according to the following equation:

$$
\delta X=\left[\left(R_{\text {sample }} / R_{\text {standard })}\right)-1\right] \times 1000
$$

where $X$ is ${ }^{13} \mathrm{C}$ or ${ }^{15} \mathrm{~N}$ and $R$ is the corresponding ratio ${ }^{13} \mathrm{C}:{ }^{12} \mathrm{C}$ or ${ }^{15} \mathrm{~N}:{ }^{14} \mathrm{~N}$. The reference standards for ${ }^{13} \mathrm{C}$ and ${ }^{15} \mathrm{~N}$ were PeeDee Belemnite (PDB) and atmospheric $\mathrm{N}_{2}$, respectively. The analytical error (SD) was 0.23 for carbon and 0.28 for nitrogen.

Each mysid sample contained 4 to 5 individuals; smaller zooplankton, 20 to 30 individuals; and Keratella and veligers, up to 50 individuals. Veligers were separated from other seston components by specific density using Ludox AM (specific gravity of 1.2). The calcareous shells of veligers were dissolved with acid (Pennington \& Hadfield 1989), which might have masked the dietary carbon signal. A total of 14 replicates of Neomysis americana, 12 replicates of Mysis stenolepis and Eurytemora affinis, 7 replicates of Bosmina longirostris, 5 replicates of nauplii and veligers and 4 replicates of Keratella sp. were analysed, depending on capture success and mass-spectrometry analysis.

Statistical analysis. Predation rate ( $P R$, ingested prey mysid $^{-1} \mathrm{~d}^{-1}$ ) was calculated as:

$$
\mathrm{PR}=\frac{\left(C_{\text {start }}-C_{\text {end }}\right)}{\text { (number of mysids } \times \text { incubation time })} \times 24
$$

where $C_{\text {start }}$ and $C_{\text {end }}$ are the number of prey in the experimental tanks $\left(t_{0}\right)$ and after incubation for $6 \mathrm{~h}$ $\left(t_{1}\right)$ and $12 \mathrm{~h}\left(t_{2}\right)$. Comparison of prey concentrations at the start, in the middle and at the end of the experiment in control treatments were used to determine prey mortality during the experiment not due to predation by mysids and to correct predation rates in mysid treatments. We calculated predation rates by a linear equation to show absolute predation, instead of normalised predation, over the experimental time of 6 and $12 \mathrm{~h}$, respectively, which is a common way to express 
predation rate in feeding experiments with mysids (e.g. Wooldridge \& Webb 1988, Aaser et al. 1995, Jerling \& Wooldridge 1995, Mohammadian et al. 1997, Viitasalo \& Rautio 1998, Winkler \& Greve 2004). As the prey density decreased over the experimental period, we calculated average prey density ( $\mathrm{PD}$, ind. $\mathrm{l}^{-1}$ ) for each experiment over the $12 \mathrm{~h}$ period, using the equation (Hansson et al. 2001):

$$
\mathrm{PD}=C_{\text {start }}\left[\mathrm{e}^{\ln \left(C_{\text {end }} / C_{\text {start })}\right.}-1 / \ln \left(C_{\text {end }} / C_{\text {start }}\right)\right]
$$

Ingestion rate (ingested biomass [DW] mysid $^{-1} \mathrm{~d}^{-1}$ ) of prey species was calculated from length and dry weight regressions found in the literature (HillbrichtIlkowska \& Stancyzkowska 1969, Dumont et al. 1975, Escaravage \& Soetaert 1993, Sprung 1993). We used 2-way MANOVA with repeated measurements (Zar 1996) to compare predation rates after $6 \mathrm{~h}$ ( 0 to $6 \mathrm{~h}$ ) and after $12 \mathrm{~h}$ ( 0 to $12 \mathrm{~h}$ ). In a second step, we divided the experimental duration of $12 \mathrm{~h}$ into two $6 \mathrm{~h}$ periods $(0$ to $6 \mathrm{~h}$ and 6 to $12 \mathrm{~h}$ ), which enabled us to determine how initial condition and resulting feeding pattern changed in the second half of the experiment. In addition to the MANOVA, we also conducted a permutation test (1000 iterations on the same model as the MANOVA described above) on the same data set, and the results were similar. To compare predation rate on each prey taxon separately we used ANOVA on ranks and contrasts, and univariate post hoc tests were also calculated on rank data using the GLM module in the SAS program (2001 version, SAS), because of unequal homogeneity of the residuals.

To compare food preferences between Mysis stenolepis and Neomysis americana, we measured dietary preferences using Manly's alpha with variable prey populations. This was necessary because of decreasing prey density and changing prey proportions due to predation over each $6 \mathrm{~h}$ observation period (Krebs 2001):

$$
\alpha_{i}=\log p_{i} / \sum \log p_{j}
$$

where $\alpha$ is Manly's alpha for prey type $i$ and $p_{i}$ and $p_{j}$ are the proportion of prey $i$ and $j$ remaining at the end of the experiment $(i=1,2,3, \ldots m),(j=1,2,3 \ldots m)$, with $p_{i}=e_{i} / n_{i}$, where $e_{i}$ is the number of prey type $i$ remaining uneaten at the end of the experiment, $n_{i}$ is the initial number of prey type $i$ and $m$ is the number of prey types. We conducted a 3 -factor ANOVA on ranks of Manly's alpha selection for each experiment. Factors were predator ( $M$. stenolepis, $N$. americana), time (0 to $6 \mathrm{~h}, 6$ to $12 \mathrm{~h}$ ) and prey depending on the experiment (all experiments: nauplii, rotifers, veligers, cyclopoid copepods; Expts 2 and 3: Eurytemora affinis Stages I to IV, E. affinis Stages V and VI, Bosmina sp.; Expt 2: harpacticoid copepods.

The following post hoc contrasts were analysed using least square means: (1) comparisons among se- lection of all potential prey items of each predator at each experimental period, (2) comparisons between experimental periods of Manly's alpha of each prey item and (3) comparisons of food selection between the 2 mysid species. The latter were restricted to the first $6 \mathrm{~h}$ period of the experiments, because food conditions in the second half of the experiments differed due to differences in the foraging behaviour of both predators.

To estimate food-niche overlap we calculated both Schoener's measure $(D)$ and Horn's index $\left(R_{0}\right)$. Schoener's measure is sensitive to unequal sample sizes, and Horn's index is recommended in such cases (Krebs 2001):

$$
\begin{gathered}
D=1-0.5\left(\sum\left|p_{i j}-p_{i k}\right|\right) \\
R_{0}=\sum\left(p_{i j}+p_{i k}\right) \log \left(p_{i j}+p_{i k}\right)- \\
\sum p_{i j} \log p_{i j}-\sum p_{i k} \log p_{i k} / 2 \log 2
\end{gathered}
$$

where $p_{i j}$ and $p_{i k}$ are the proportions of the resource $i$ in the diet of species $j$ and $k$. Both indices range from 0 (no overlap) to 1 (complete overlap) (Smith \& Zaret 1982, Wallace \& Ramsey 1983). An index value of 0.7 indicates an overlap of $70 \%$ of the diet of both predators, expressed in percent contribution of the various categories. We calculated the food-niche overlap of Mysis stenolepis and Neomysis americana from the average predation on prey items in each experiment with 4 prey categories in Expt 1, 8 prey categories in Expt 2 and 7 prey categories in Expt 3.

\section{RESULTS}

\section{Overall predation of Neomysis americana and Mysis stenolepis}

A multiple analysis of variance with repeated measurements (MANOVA, 2 time steps) on overall predation rates on all prey groups revealed significant interactions between predators and time steps $(0$ to $6 \mathrm{~h}$ vs. 0 to 12 h) in Expt 2 and Expt 3. Contrasts between predators and between time steps showed significant differences in all comparisons (Table 2a). After $6 \mathrm{~h}$ of feeding ( 0 to 6 h) in Expt 1, Neomysis americana showed significantly higher predation rates than Mysis stenolepis, whereas in both high food concentration experiments (Expt 2 and Expt 3), M. stenolepis took prey at a significantly higher rate than $N$. americana (Table 2 , Fig. 1c). The same pattern could be seen in ingestion rates (Fig. 1d), but the difference in ingested biomass between the 2 predator species was even greater than the difference in predation rate in Expt 2 and Expt 3, which suggests that the 2 predators were not feeding on the same prey types (Fig. 1d). Over the entire $12 \mathrm{~h}$ period ( 0 to $12 \mathrm{~h}$ ) both predators had patterns in overall predation and ingestion similar to those in the 0 to 
$6 \mathrm{~h}$ time period, but the predation rate was significantly lower (Table 2b), due to a decrease in predation over the second $6 \mathrm{~h}$ time period ( 6 to $12 \mathrm{~h}$ ). As we also analysed the second half of the experiment (6 to $12 \mathrm{~h}$ ) separately, the initial food conditions for both species differed. In all 3 experiments, food concentrations were higher and biomass concentrations were lower (Expt 2 and Expt 3) in tanks with the predator
M. stenolepis than in tanks with $N$. americana (Fig. 1a,b). Under these new conditions, predation rates decreased relative to the first part of the experiments for both predators and in all experiments, probably due to lower prey concentrations (Fig. 1e). However, in Expt 2 biomass consumed by $N$. americana during 6 to $12 \mathrm{~h}$ was significantly higher than in 0 to 6 h (Fig. 1f).
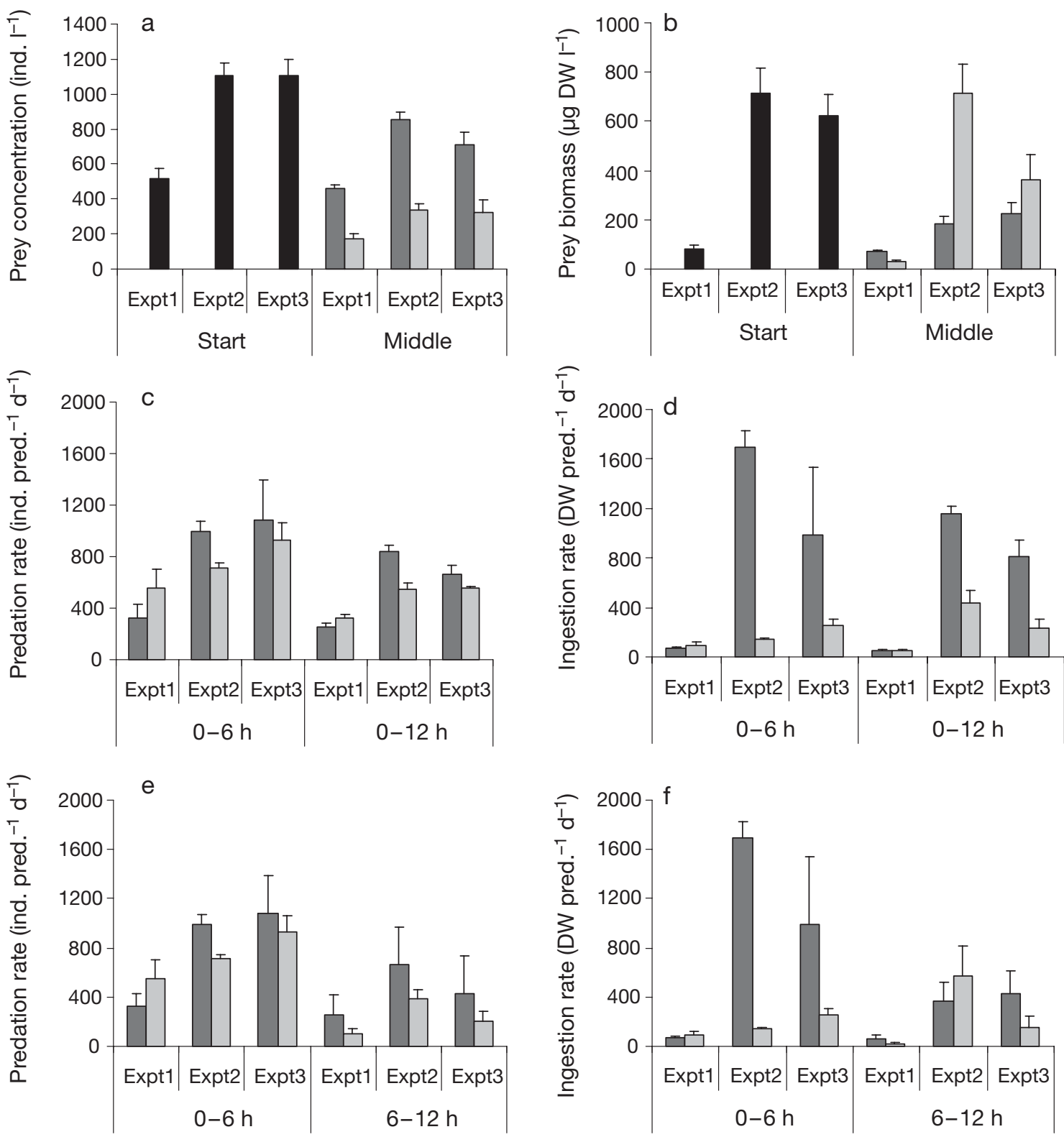

Fig. 1. (a) Total prey concentration in individuals per litre and (b) prey biomass in micrograms dry weight (DW) per litre, at the beginning (Start, black columns) and after $6 \mathrm{~h}$ (Middle, grey columns; see shading distinction below) of the 3 feeding experiments. Mysis stenolepis (dark grey) and Neomysis americana (light grey) $(\mathrm{c}, \mathrm{e})$ total predation rate (ind. predator $\left.^{-1} \mathrm{~d}^{-1}\right)$, and $(\mathrm{d}, \mathrm{f})$ total ingestion rate (DW predator $\left.{ }^{-1} \mathrm{~d}^{-1}\right),(\mathrm{c}, \mathrm{d})$ in the first half $(0$ to $6 \mathrm{~h})$ of the experiment and over the entire experimental period ( 0 to $12 \mathrm{~h}$ ) and (e,f) in 2 consecutive experimental periods ( 0 to $6 \mathrm{~h}$ and 6 to $12 \mathrm{~h}$ ). Error bars: SD 
Table 2. Comparisons of overall predation rates of various prey items by a multiple analysis of variance (MANOVA) with repeated measurements. The first factor is predator (pred.) with 2 levels Mysis stenolepis (M.s.) and Neomysis americana (N.a.), the second factor is time with 2 levels. (a) Two levels of factor time are the first $6 \mathrm{~h}$ period ( 0 to $6 \mathrm{~h}$ ) and the entire experimental duration $(0$ to $12 \mathrm{~h}$ ) and (b) 2 levels of factor time are the first $6 \mathrm{~h}$ period ( 0 to $6 \mathrm{~h}$ ) and the second $6 \mathrm{~h}$ period ( 6 to $12 \mathrm{~h}$ ) of Expts 1 to 3. n.s.: not significant

\begin{tabular}{|c|c|c|c|c|c|c|c|}
\hline & \multirow[t]{2}{*}{ Factor } & \multicolumn{2}{|c|}{ Expt 1} & \multicolumn{2}{|r|}{ Expt 2} & \multicolumn{2}{|r|}{ Expt 3} \\
\hline & & df & $\mathrm{p}$ & $\mathrm{df}$ & $\mathrm{p}$ & $\mathrm{df}$ & $\mathrm{p}$ \\
\hline \multirow[t]{7}{*}{ (a) } & Predator & 4 & 0.0109 & 8 & 0.002 & 7 & 0.0002 \\
\hline & Time & 4 & 0.0037 & 8 & 0.004 & 7 & 0.0007 \\
\hline & Pred. $\times$ Time & 4 & n.s. & 8 & 0.0071 & 7 & 0.0002 \\
\hline & $\begin{array}{l}\text { M. stenolepis } \\
(0-6 \text { h vs. } 0-12 \text { h) }\end{array}$ & 4 & & 8 & 0.002 & 7 & 0.0002 \\
\hline & $\begin{array}{l}\text { N. americana } \\
(0-6 \text { h vs. } 0-12 \text { h) }\end{array}$ & 4 & & 8 & 0.023 & 7 & 0.0015 \\
\hline & 0-6 h (M.s. vs. N.a.) & 4 & & 8 & 0.003 & 7 & $<0.0001$ \\
\hline & 0-12 h (M.s. vs. N.a.) & 4 & & 8 & 0.0015 & 7 & $<0.0001$ \\
\hline \multirow[t]{7}{*}{ (b) } & Predator & 4 & 0.0109 & 8 & $<0.0001$ & 7 & $<0.0001$ \\
\hline & Time & 4 & 0.006 & 8 & $<0.0001$ & 7 & 0.003 \\
\hline & Pred. $\times$ Time & 4 & 0.0459 & 8 & $<0.0001$ & 7 & 0.0002 \\
\hline & $\begin{array}{l}\text { M. stenolepis } \\
(0-6 \text { h vs. } 6-12 \text { h) }\end{array}$ & 4 & 0.0025 & 8 & 0.001 & 7 & 0.0002 \\
\hline & $\begin{array}{l}\text { N. americana } \\
(0-6 \text { h vs. } 6-12 \text { h) }\end{array}$ & 4 & 0.0028 & 8 & 0.0033 & 7 & 0.0023 \\
\hline & 0-6 h (M.s. vs. N.a.) & 4 & 0.0007 & 8 & $<0.0001$ & 7 & $<0.0001$ \\
\hline & 6-12 h (M.s. vs. N.a.) & 4 & 0.0105 & 8 & 0.0008 & 7 & n.s. \\
\hline
\end{tabular}

(Fig. 2d). The proportion in the prey field of Bosmina longirostris in terms of abundance and biomass was low. Nevertheless, both predators preyed upon $B$. longirostris so that a disproportionate fraction of their ingested diet was composed of B. longirostris, $6 \%$ in $M$. stenolepis and $17 \%$ in $N$. americana in Expt 2 (Fig. 2d), suggesting selection for $B$. longirostris.

In Expt 3 ( 7 prey taxa), the ingested prey by Mysis stenolepis consisted of $20 \%$ large prey items (copepods and cladocerans), whereas Neomysis americana preferred small prey items (veligers, rotifers and nauplii), representing $97 \%$ of the diet (Fig. 2c). Most of the ingested biomass of M. stenolepis was composed of copepod prey. In contrast, $55 \%$ of ingested biomass in the diet of $N$. americana was still derived from small prey (veligers, rotifers and nauplii) in Expt 3 (Fig. 2d).

Feeding patterns changed in the second half of the experiments (6 to $12 \mathrm{~h}$ ). The proportion of nauplii (abundance and biomass) eaten by Mysis stenolepis decreased in the latter half of all experiments compared to the first half $(0$ to $6 \mathrm{~h}$ ), whereas a higher proportion of veligers was consumed. The

\section{Diet composition and predation on various prey taxa}

Much of the variation seen in total numbers and biomass of ingested food was explained by examining the consumption of individual prey species (Fig. 2). In the first period (0 to $6 \mathrm{~h}$ ) of Expt 1 involving 4 prey taxa, Mysis stenolepis mostly consumed nauplii and rotifers (Fig. 2c), in contrast to the available food composition (Fig. 2a). Only $10 \%$ of ingested prey was veligers, the most abundant prey (63\%). In contrast, $50 \%$ of the food consumed by Neomysis americana was veligers: smaller fractions of rotifers $(25 \%)$ and nauplii $(28 \%)$ were consumed (Fig. 2c). Similar results were seen for ingested biomass (Fig. 2d), with nauplii dominating the diet of $M$. stenolepis, whereas $N$. americana ingested almost similar proportions of veliger and nauplii biomass (Fig. 2d).

In Expt 2 (8 prey taxa), the prey ingested by Mysis stenolepis consisted of $50 \%$ (Expt 2) large prey items, such as copepods and cladocerans, whereas $>95 \%$ of the diet of Neomysis americana was composed of small prey items-veligers, rotifers and nauplii (Fig. 2c). Most of the ingested biomass of $M$. stenolepis was composed of copepod prey. In contrast, $70 \%$ of ingested biomass in the diet of $N$. americana was derived from small prey (veligers, rotifers and nauplii) in Expt 2 proportion of food items taken by Neomysis americana showed a shift from small prey towards higher proportions of copepod prey in terms of abundance as well as biomass in Expt 2 and Expt 3 (Fig. 2e,f).

Highest predation rates of Mysis stenolepis were on nauplii and small Eurytemora affinis copepodites (Stages I to IV), whereas predation rates of Neomysis americana were highest on veligers, followed by either nauplii in Expt 1 and Expt 3 or rotifers in Expt 2. Predation rates on large prey items (copepod species and Bosmina longirostris) and on the small prey item, nauplii, of $M$. stenolepis were significantly higher, whereas predation rates on veligers and rotifers were significantly lower than those of $N$. americana in the first half of all 3 experiments (Tables $3 \& 4$, Figs. 3 to 5). Differences in predation rate in 6 to $12 \mathrm{~h}$ cannot be reliably interpreted because 'initial' prey densities differed between predators for this period of the experiment. Considering the initial concentrations of each food item, M. stenolepis consumed the less abundant prey instead of feeding on the highly abundant veligers. In contrast, predation rates of $N$. americana coincided with the concentration of prey items in the food assemblage, suggesting density-dependent feeding behaviour.

Both predators generally decreased predation rates significantly in the second half of the experiment 


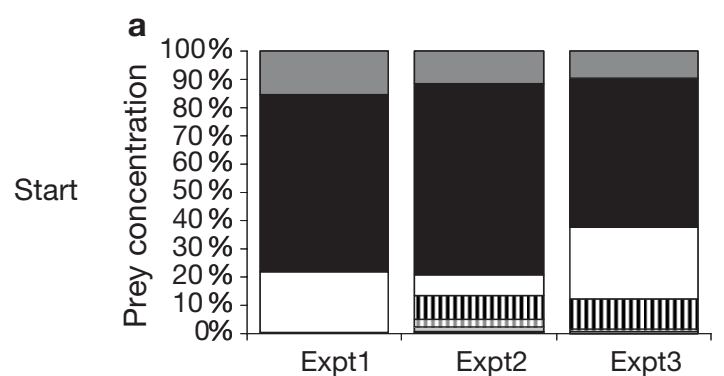

b
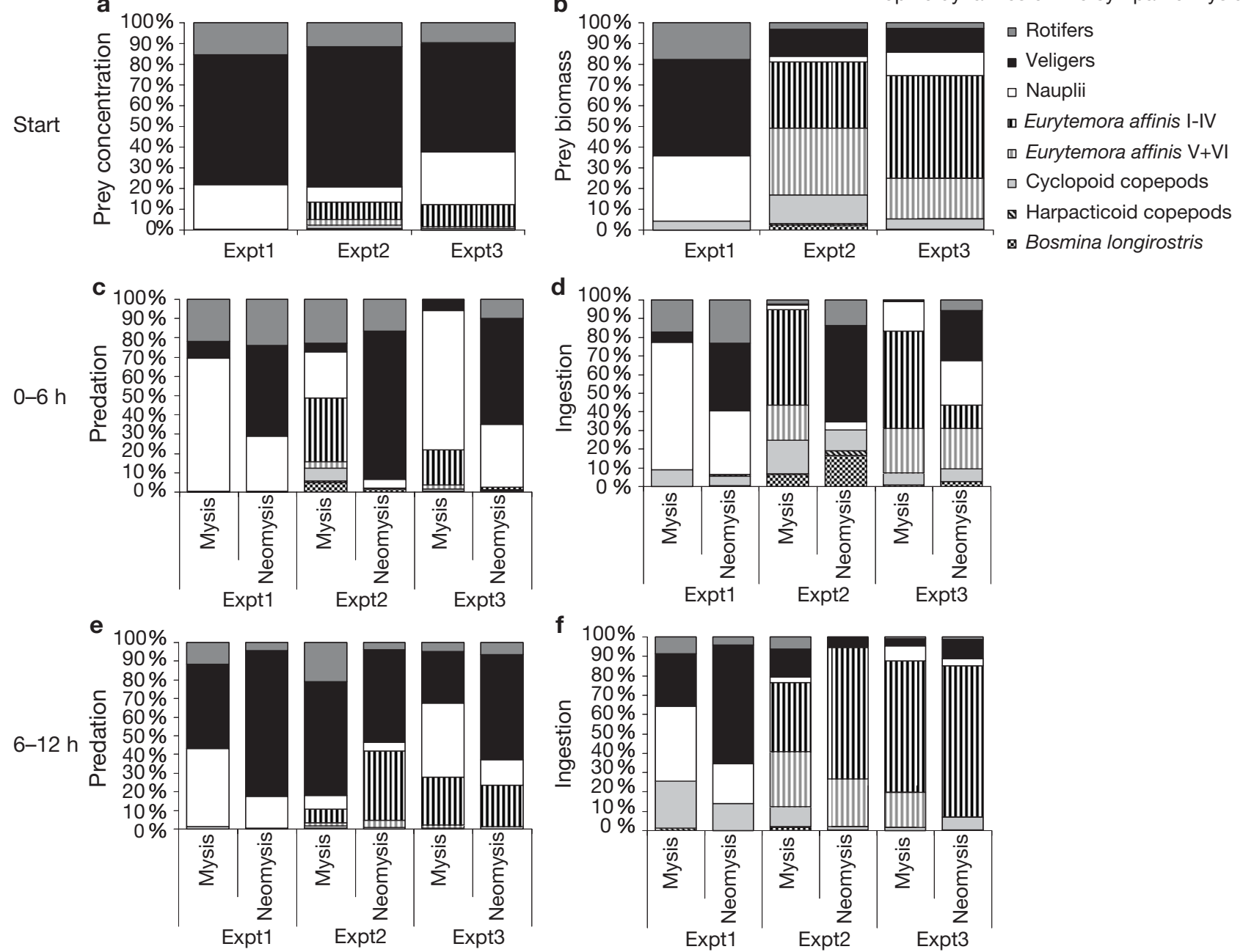

Fig. 2. Zooplankton composition in the prey assemblage in terms of (a) abundance and (b) biomass; diet composition of Mysis stenolepis and Neomysis americana in terms of $(\mathrm{c}, \mathrm{e})$ predation and $(\mathrm{d}, \mathrm{f})$ ingested biomass in the first experimental period $(\mathrm{c}, \mathrm{d}$; 0 to $6 \mathrm{~h}$ ) and in the second experimental period (e,f; 6 to $12 \mathrm{~h})$

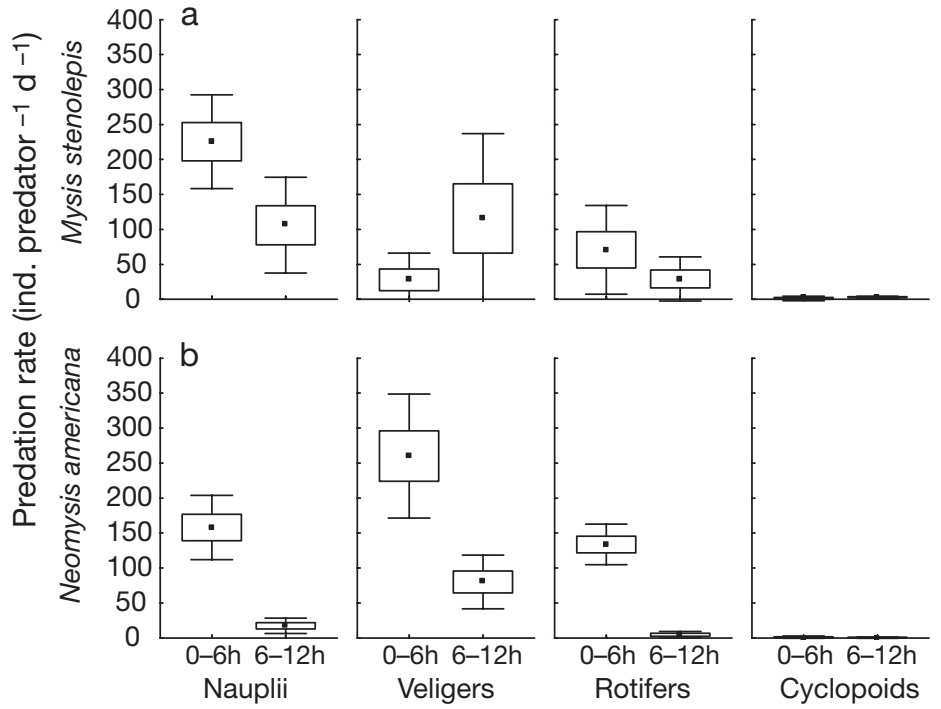

Fig. 3. Predation rates on nauplii, veligers, rotifers and cyclopoid copepods by: (a) Mysis stenolepis and (b) Neomysis americana in Expt 1 in 2 consecutive experimental periods ( 0 to $6 \mathrm{~h}$ and 6 to $12 \mathrm{~h}$ ). Predation rates are expressed as means (dots), standard error (boxes) and standard deviation (error bars) 
Table 3. Results of analysis of variance (ANOVA) on rank data of predation rate on each prey taxon for all 3 feeding experiments Predator (pred.): Mysis stenolepis (M) and Neomysis americana (N); time: 2 consecutive time intervals of 0 to $6 \mathrm{~h}$ and 6 to $12 \mathrm{~h}$. n.s.: not significant

\begin{tabular}{|c|c|c|c|c|c|c|c|}
\hline \multirow[t]{2}{*}{ Prey } & \multirow[t]{2}{*}{ Factor } & \multicolumn{3}{|c|}{ Experiments } & \multicolumn{3}{|c|}{ Rank of predation rate } \\
\hline & & Expt 1 & Expt 2 & Expt 3 & Expt 1 & Expt 2 & Expt 3 \\
\hline \multirow[t]{3}{*}{ Nauplii } & Predator & 0.0158 & $<0.0001$ & $<0.0001$ & $M>N$ & $M>N$ & $M>N$ \\
\hline & Time & 0.0001 & 0.0021 & $<0.0001$ & $0-6>6-12$ & $0-6>6-12$ & $0-6>6-12$ \\
\hline & Pred. $\times$ Time & n.s. & n.s. & n.s. & & & \\
\hline \multirow[t]{3}{*}{ Rotifers } & Predator & 0.0028 & $<0.0001$ & 0.0021 & & $\mathrm{M}>\mathrm{N}$ & \\
\hline & Time & 0.0002 & $<0.0001$ & $<0.0001$ & & $0-6>6-12$ & \\
\hline & Pred. $\times$ Time & 0.0413 & n.s. & $<0.0001$ & (Table 4) & & (Table 4) \\
\hline \multirow[t]{3}{*}{ Veligers } & Predator & 0.0028 & 0.021 & 0.0006 & & & \\
\hline & Time & 0.0002 & n.s. & 0.0025 & & & \\
\hline & Pred. $\times$ Time & 0.0413 & 0.0001 & 0.0248 & (Table 4) & (Table 4) & (Table 4) \\
\hline \multirow[t]{3}{*}{ Eurytemora affinis I-IV } & Predator & & 0.0028 & $<0.0001$ & & & $\mathrm{M}>\mathrm{N}$ \\
\hline & Time & & n.s. & n.s. & & & \\
\hline & Pred. $\times$ Time & & $<0.0001$ & n.s. & & (Table 4) & \\
\hline \multirow{3}{*}{ E. affinis $\mathrm{V}-\mathrm{VI}$} & Predator & & 0.0028 & $<0.0001$ & & & $\mathrm{M}>\mathrm{N}$ \\
\hline & Time & & n.s. & n.s. & & & \\
\hline & Pred. $\times$ Time & & $<0.0001$ & n.s. & & (Table 4) & \\
\hline \multirow[t]{3}{*}{ Bosmina longirostris } & Predator & & $<0.0001$ & $<0.0001$ & & $\mathrm{M}>\mathrm{N}$ & $\mathrm{M}>\mathrm{N}$ \\
\hline & Time & & 0.002 & $<0.0001$ & & $0-6>6-12$ & $0-6>6-12$ \\
\hline & Pred. $\times$ Time & & n.s. & n.s. & & & \\
\hline \multirow[t]{3}{*}{ Cyclopoid copepods } & Predator & n.s. & 0.0003 & n.s. & & $\mathrm{M}>\mathrm{N}$ & \\
\hline & Time & n.s. & 0.006 & 0.02 & & $0-6>6-12$ & $0-6>6-12$ \\
\hline & Pred. $\times$ Time & n.s. & n.s. & n.s. & & & \\
\hline \multirow[t]{3}{*}{ Harpacticoid copepods } & Predator & & n.s. & & & & \\
\hline & Time & & $<0.0001$ & & & & \\
\hline & Pred. $\times$ Time & & 0.0006 & & & (Table 4) & \\
\hline
\end{tabular}

(6 to 12 h) (Tables $3 \& 4$, Figs. 3 to 5) with 3 exceptions. Predation rate on veligers of Mysis stenolepis was lowest in the first $6 \mathrm{~h}$ period ( 0 to $6 \mathrm{~h}$ ) and increased significantly in the 6 to $12 \mathrm{~h}$ period in Expt 2 (Table 4, Fig. 4). Furthermore, predation rates of Neomysis americana on all Eurytemora affinis copepodites (Stages I to IV and V and VI) were significantly higher in the second period (6 to 12 h) of Expt 2 (Fig. 4, Table 4). Although not statistically significant, similar trends were seen in the other 2 experiments as well (Figs. $3 \& 5$ ).

In summary, predation rate of Mysis stenolepis on most prey species decreased in the second half of the

Table 4. Post hoc comparisons of rank data by contrasts of predation rates of various prey items and of each mysid predator Mysis stenolepis (M) and Neomysis americana $(\mathrm{N})$ and the 2 consecutive time intervals of 0 to $6 \mathrm{~h}$ and 6 to $12 \mathrm{~h}$. Comparisons were only done when there were significant interactions between the factors Predator and Time (see Table 3). n.s.: not significant

\begin{tabular}{|c|c|c|c|c|}
\hline Prey & Contrast & Expt 1 & Expt 2 & Expt 3 \\
\hline Rotifers & $\begin{array}{l}\text { M. stenolepis: } 0-6 \mathrm{~h} \text { vs. } 6-12 \mathrm{~h} \\
\text { N. americana: } 0-6 \mathrm{~h} \text { vs. } 6-12 \mathrm{~h} \\
0-6 \text { h: M. stenolepis vs. } N \text {. americana }\end{array}$ & $\begin{array}{c}\text { n.s. } \\
0-6>6-12 \\
\mathrm{~N}>\mathrm{M}\end{array}$ & & $\begin{aligned} \text { n.s. } \\
0-6>6-12 \\
\mathrm{~N}>\mathrm{M}\end{aligned}$ \\
\hline Veligers & $\begin{array}{l}\text { M. stenolepis: } 0-6 \mathrm{~h} \text { vs. } 6-12 \mathrm{~h} \\
\text { N. americana: } 0-6 \mathrm{~h} \text { vs. } 6-12 \mathrm{~h} \\
0-6 \text { h: } M . \text { stenolepis vs. } N \text {. americana }\end{array}$ & $\begin{aligned} \text { n.s. } \\
0-6>6-12 \\
\mathrm{~N}>\mathrm{M}\end{aligned}$ & $\begin{array}{c}6-12>0-6 \\
0-6>6-12 \\
N>M\end{array}$ & $\begin{aligned} \text { n.s. } \\
0-6>6-12 \\
\mathrm{~N}>\mathrm{M}\end{aligned}$ \\
\hline Eurytemora affinis I-IV & $\begin{array}{l}\text { M. stenolepis: } 0-6 \mathrm{~h} \text { vs. } 6-12 \mathrm{~h} \\
\text { N. americana: } 0-6 \mathrm{~h} \text { vs. } 6-12 \mathrm{~h} \\
0-6 \text { h: M. stenolepis vs. } N \text {. americana }\end{array}$ & & $\begin{array}{l}0-6>6-12 \\
6-12>0-6 \\
M>N\end{array}$ & \\
\hline E. affinis V-VI & $\begin{array}{l}\text { M. stenolepis: } 0-6 \mathrm{~h} \text { vs. } 6-12 \mathrm{~h} \\
\text { N. americana: } 0-6 \mathrm{~h} \text { vs. } 6-12 \mathrm{~h} \\
0-6 \text { h: M. stenolepis vs. } N \text {. americana }\end{array}$ & & $\begin{array}{l}0-6>6-12 \\
6-12>0-6 \\
M>N\end{array}$ & \\
\hline Harpacticoid copepods & $\begin{array}{l}\text { M. stenolepis: } 0-6 \mathrm{~h} \text { vs. } 6-12 \mathrm{~h} \\
\text { N. americana: } 0-6 \mathrm{~h} \text { vs. } 6-12 \mathrm{~h} \\
0-6 \text { h: M. stenolepis vs. } N \text {. americana }\end{array}$ & & $\begin{aligned} 0-6 & >6-12 \\
0-6 & >6-12 \\
M & >\mathrm{N}\end{aligned}$ & \\
\hline
\end{tabular}




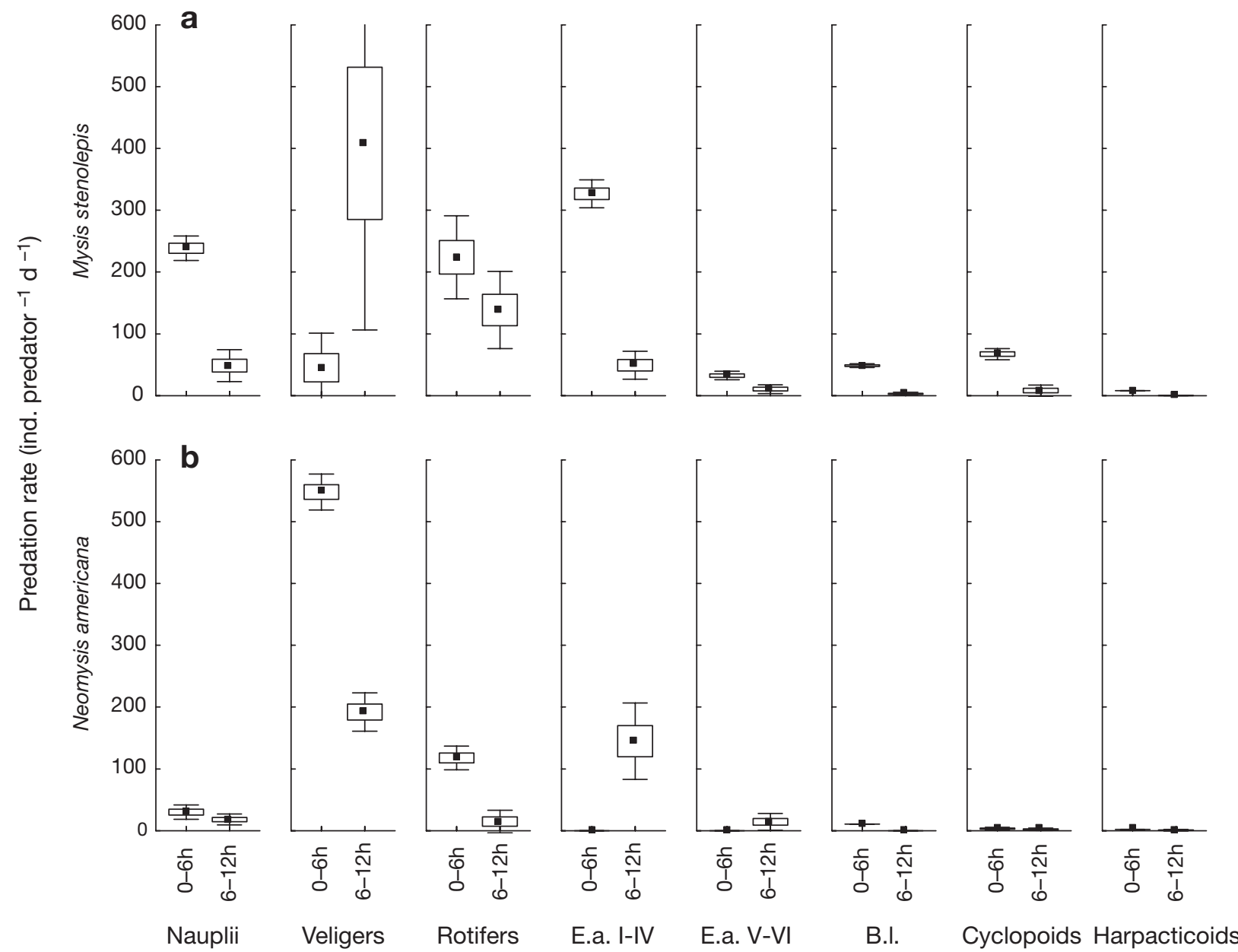

Fig. 4. Predation rates on nauplii, veligers, rotifers, Eurytemora affinis (E.a.) Stages I to IV and Stages V and VI, Bosmina longirostris (B.1.), cyclopoid and harpacticoid copepods by: (a) Mysis stenolepis and (b) Neomysis americana in Expt 2 in 2 consecutive experimental periods ( 0 to $6 \mathrm{~h}$ and 6 to $12 \mathrm{~h}$ ). Predation rates are expressed as means (dots), standard error (boxes) and standard deviation (error bars)

experiment (6 to $12 \mathrm{~h}$ ), except for veligers and rotifers, suggesting increased filter feeding when copepod densities become low in the experiments. Neomysis americana showed the opposite pattern, with higher predation on Eurytemora affinis copepods when predation of small prey decreased due to decreasing density in the second part of the experiments. These results were supported by significant positive correlations between prey densities and predation rates (data not shown).

To estimate the effect of alternative prey on the predation rates on any particular prey species, we examined the relationship between alternative prey densities on predation rates of that species assuming that densities of the tested prey pair were not initially correlated. Veliger predation was negatively correlated with Eurytemora affinis (Stages I to IV) density ( $\mathrm{r}=$ $-0.46, \mathrm{p} \leq 0.05)$, and rotifer predation was negatively correlated with nauplii density $(\mathrm{r}=-0.45, \mathrm{p} \leq 0.05)$ in Mysis stenolepis. E. affinis (Stages I to IV) predation was reduced by rotifer density $(\mathrm{r}=-0.4, \mathrm{p} \leq 0.05)$ in Neomysis americana.

Food-niche overlap (similarity of the diets) between Mysis stenolepis and Neomysis americana decreased with increasing prey field (number of prey taxa), from 0.59 to 0.34 overlap (Schoener) and from 0.84 to 0.35 (Horn's index). Food-niche overlap calculated by Schoener showed highest overlap $59 \%$ in Expt 1. The food niches of both predators became more distinct in the other 2 experiments (Expt 2: 0.34; Expt 3: 0.41). Despite higher niche overlap revealed by the Horn index, Expt 2 showed highest differentiation in diet as the Schoener measure (Expt 1: 0.84; Expt 2: 0.35; Expt 3: 0.65). In general, differentiation of feeding pattern increased when a larger prey field was available. 


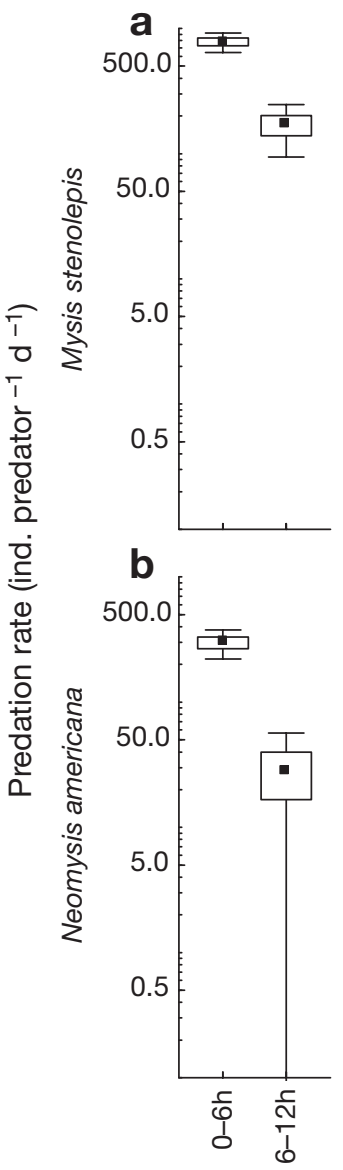

Nauplii
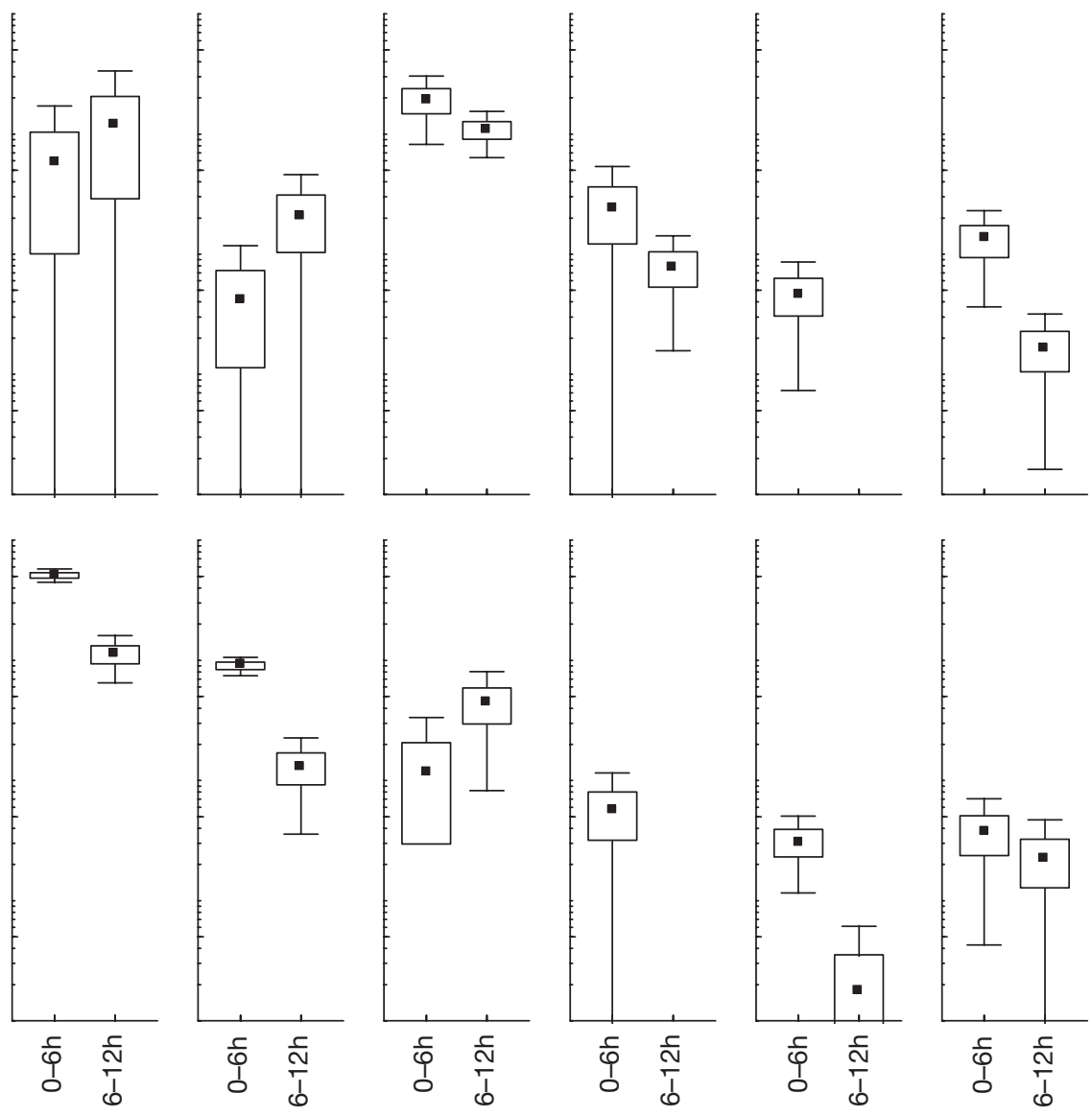

E.a. I-IV

E.a. V-IV

B. longirostris

Cyclopoids

Fig. 5. Predation rates on nauplii, veligers, rotifers, Eurytemora affinis (E.a.) Stages I to IV and Stages V and VI, Bosmina longirostris, and cyclopoid copepods by (a) Mysis stenolepis and (b) Neomysis americana in Expt 3 in 2 consecutive experimental periods ( 0 to $6 \mathrm{~h}$ and 6 to $12 \mathrm{~h}$ ). Predation rates are expressed as means (dots), standard error (boxes) and standard deviation (error bars) on a logarithmic scale in order to show low predation rates as well as high predation rates

\section{Prey selection}

A 3-factor ANOVA on the selection index Manly's alpha revealed significant interactions between predator $\times$ prey and time $\times$ prey in Expt 1 and a significant interaction among all 3 factors (predator $\times$ time $\times$ prey) in Expt 2 and Expt 3, indicating that selection differed among predators, prey items and experimental periods (Table 5). Mysis stenolepis selected Eurytemora affinis nauplii and E. affinis copepodites (all stages), when available, significantly over small prey such as veligers and rotifers, which were least selected in all 3 experiments. Selection for Bosmina longirostris, cyclopoid and harpacticoid copepods was not consistent; position of selection changed depending on the experiment and experimental period (Table 6). Selection pattern changed significantly from the first to the second experimental period for several prey items. Significantly higher selection in period 0 to $6 \mathrm{~h}$ by M. stenolepis was observed for harpacticoid copepods (Expt 2), and a significant increase in selection of young $E$. affinis stages (I to IV) was seen in Expt 2 and Expt 3. Selection for $B$. longirostris and cyclopoid copepods was similar in both periods in Expt 2, but decreased significantly in the second period ( 6 to $12 \mathrm{~h}$ ) in Expt 3.

In general, Neomysis americana preferred significantly smaller prey (rotifers, nauplii and veligers) over copepod prey. However, an exceptionally high selection for Bosmina longirostris was found in the first period of Expt 2, but decreased significantly in the second period of Expt 2 only for $N$. americana. In contrast, selection for young Eurytemora affinis stages (I to IV) increased significantly in the second period of Expt 2 compared to the first period (Table 6).

The comparison of selection of prey taxa among predators revealed that, in general, selection for larger 
prey, such as Eurytemora affinis, cyclopoid copepods and harpacticoid copepods, was higher in Mysis stenolepis than in Neomysis americana. In contrast, N. americana showed higher preference in all 3 experiments for small prey such as veligers and rotifers compared to M. stenolepis. Selection for nauplii and Bosmina longirostris was not significantly different between both predators in all experiments (Table 6, Fig. 6).

\section{Trophic position in the food web}

Mysis stenolepis and Neomysis americana showed similar ( $t$-test, $t=-0.99, \mathrm{p}=0.33$ ) carbon isotopic values, with a mean of $-20.2 \pm 0.2 \%$ o $\delta^{13} \mathrm{C}$ (Fig. 7 ). With regard

Table 5. Comparison of food selection (Manly's alpha) by a 3factor ANOVA on ranks carried out for each experiment. Factors were predator (Mysis stenolepis, Neomysis americana), time (0 to $6 \mathrm{~h}, 6$ to $12 \mathrm{~h}$ ) and prey, depending on the experiment (all experiments: nauplii, rotifers, veligers, cyclopoid copepods; Expts 2 and 3: Eurytemora affinis Stages I to IV, E. affinis Stages V and VI, Bosmina longirostris; and Expt 2:

harpacticoid copepods). Bold print: significant at $\mathrm{p} \leq 0.01$

\begin{tabular}{|c|c|c|c|c|}
\hline Source & df & MS F & F & $\mathrm{p}$ \\
\hline \multicolumn{5}{|l|}{ Expt 1} \\
\hline Model & 25 & 1509.693 & 3.01 & 0.0002 \\
\hline Error & 70 & 501.303 & & \\
\hline Corrected total & 95 & & & \\
\hline Predator & 1 & 459.375 & 0.92 & 0.3417 \\
\hline Time & 1 & 38.760 & 0.08 & 0.7818 \\
\hline Prey & 3 & 4283.479 & 8.54 & $<0.0001$ \\
\hline Predator $\times$ Time & 1 & 110.510 & 0.22 & 0.6402 \\
\hline Predator × Prey & 3 & 3721.549 & 7.42 & 0.0002 \\
\hline Time $\times$ Prey & 3 & 3326.781 & 6.64 & 0.0005 \\
\hline Predator $\times$ Time $\times$ Prey & 3 & 830.892 & 1.66 & 0.1841 \\
\hline \multicolumn{5}{|l|}{ Expt 2} \\
\hline Model & 41 & 9039.329 & 6.42 & $<0.0001$ \\
\hline Error & 150 & 1407.180 & & \\
\hline Corrected total & 191 & & & \\
\hline Predator & 1 & 2008.547 & 1.43 & 0.2341 \\
\hline Time & 1 & 2093.521 & 1.49 & 0.2245 \\
\hline Prey & 7 & 5951.155 & 4.23 & 0.0003 \\
\hline Predator $\times$ Time & 1 & 210.422 & 0.15 & 0.6995 \\
\hline Predator $\times$ Prey & 7 & 24711.737 & 17.56 & $<0.0001$ \\
\hline Time $\times$ Prey & 7 & 17237.842 & 12.25 & $<0.0001$ \\
\hline Predator $\times$ Time $\times$ Prey & 7 & 4268.898 & 3.03 & 0.0052 \\
\hline \multicolumn{5}{|l|}{ Expt 3} \\
\hline Model & 37 & 7600.556 & 8.93 & $<0.0001$ \\
\hline Error & 130 & 850.915 & & \\
\hline Corrected total & 167 & & & \\
\hline Predator & 1 & 111.720 & 0.13 & 0.7177 \\
\hline Time & 1 & 1400.149 & 1.65 & 0.2019 \\
\hline Prey & 6 & 5867.729 & 6.9 & $<0.0001$ \\
\hline Predator $\times$ Time & 1 & 69.429 & 0.08 & 0.7756 \\
\hline Predator × Prey & 6 & 29562.165 & 34.74 & $<0.0001$ \\
\hline Time $\times$ Prey & 6 & 5578.288 & 6.56 & $<0.0001$ \\
\hline Predator $\times$ Time $\times$ Prey & 6 & 5435.741 & 6.39 & $<0.0001$ \\
\hline
\end{tabular}

to their nitrogen isotopic ratios, $M$. stenolepis had a significantly higher value $\left(13.7 \pm 0.5 \% \delta^{15} \mathrm{~N}\right)$ than $N$. americana $\left(11.5 \pm 0.1 \% \delta^{15} \mathrm{~N}\right.$; $t$-test, $\left.t=4.79, \mathrm{p}<0.001\right)$, suggesting a different composition of prey items in their diets. The 3 mesozooplankton species investigated,


N. americana Manly's alpha

\begin{tabular}{|ll|}
\hline Nauplii & $\diamond$ Eurytemora affinis V+VI \\
$\square$ Veligers & $\triangle$ Bosmina longirostris \\
$\Delta$ Rotifers & O Cyclopoid copepods \\
$\square$ Eurytemora affinis I-IV & * Harpacticoid copepods \\
\hline
\end{tabular}

Fig. 6. Comparison of selectivity indices (Manly's alpha) of $M y$ sis stenolepis and Neomysis americana during the first period (0 to $6 \mathrm{~h}$ ) of all 3 experiments. Data points above the diagonal indicate higher selection for specific prey by $M$. stenolepis, data points below the diagonal show higher selection for specific prey by $N$. americana and data points on the diagonal indicate similar selectivity by both mysids. Error bars: $\pm \mathrm{SE}$ 
Eurytemora affinis (2 age classes: adults and nauplii), Bosmina longirostris and Keratella sp., showed very similar $\delta^{13} \mathrm{C}$ signatures $(-21.3 \pm 0.2 \%,-21.0 \pm 1.03 \%$, $-20.5 \pm 0.1 \%$ and $20.7 \pm 0.2 \%$, respectively) that overlapped with those of mysids, indicating that these mesozooplankton species are potential prey for the mysids. In contrast, Dreissena polymorpha veligers and the seston pool had a lower $\delta^{13} \mathrm{C}$ signature $(-23.8 \pm$ $1.4 \%$ and $-27 \pm 0.1 \%$, respectively) than the rest of the mesozooplankton, suggesting a less important role as

Table 6. Selected post hoc comparisons of food selection (Manly's alpha) based on least-squares means for significant interactions of a 3-factor ANOVA carried out for all 3 experiments. Factors were predator (Mysis stenolepis, Neomysis americana), time (0 to $6 \mathrm{~h}$, 6 to $12 \mathrm{~h}$ ) and prey (N: nauplii; R: rotifers; V: veligers; C: cyclopoid copepods; Ej: Eurytemora affinis Stages I to IV; Ea: E. affinis Stages $\mathrm{V}$ and VI; B: Bosmina longirostris; $\mathrm{H}$ : harpacticoid copepods). In multiple comparisons tests, prey items are ordered by decreasing ranks from left to right and non-significant differences among prey items are underlined. In pairwise comparisons only significant differences between prey items are shown, indicating significantly higher $(>)$ or significantly lower $(<)$ preference $(p<0.05)$

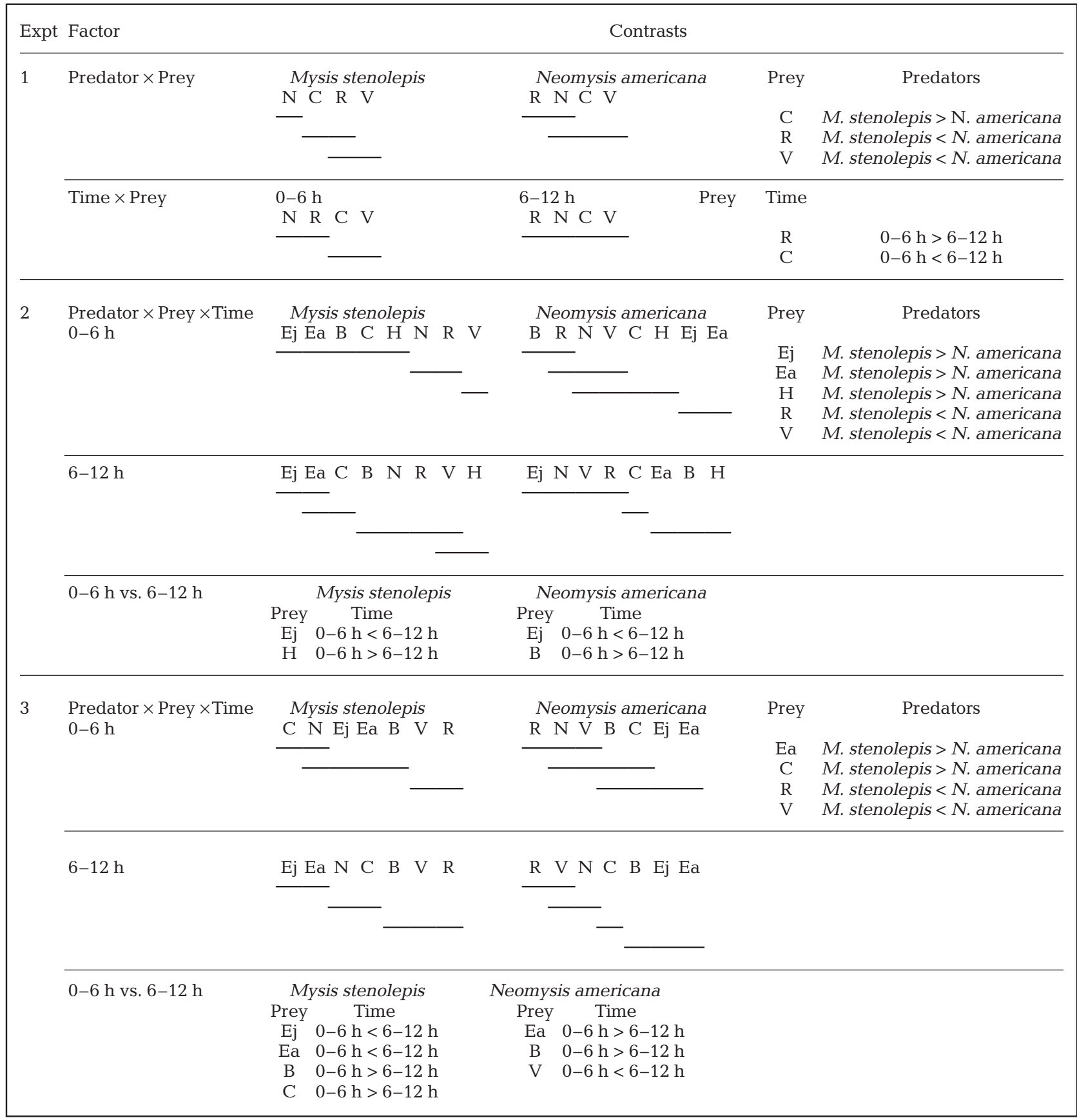




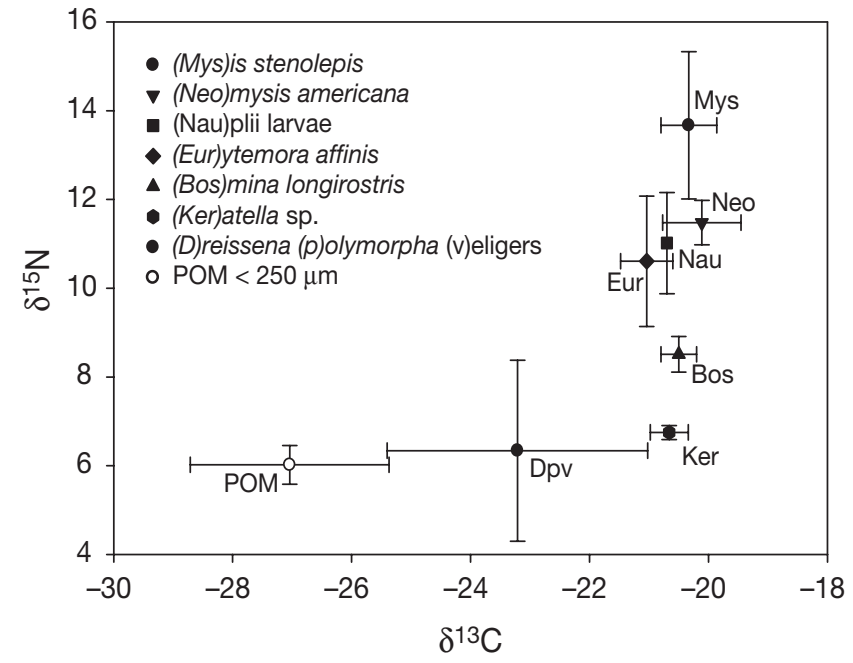

Fig. 7. Dual isotope plot for the 2 co-occurring mysids (Mysis stenolepis and Neomysis americana) and their prey in the southern channel of the St. Lawrence Estuary, July to August 2001. Each value is the mean $( \pm \mathrm{SD})$ of all samples; replicates ranged between 4 and 14. POM: particulate organic matter

food items for mysids. According to differences in nitrogen signatures of prey, the mass-balanced assimilation of different prey compositions resulted in a difference of trophic levels of both mysid predators.

\section{DISCUSSION}

\section{Contrasting foraging strategies of Mysis stenolepis and Neomysis americana}

The patterns of predation and selection on natural zooplankton assemblages of the ETZ demonstrate clearly that the 2 mysid species differ in their feeding niche, but are responsive and adaptable in their feeding behaviour to varying prey densities and composition. Predation by Mysis stenolepis responded to the availability of Eurytemora affinis copepodites and nauplii, showing highest predation rates on either prey depending on its availability in the food assemblage. Increased predation on veligers by $M$. stenolepis was observed in the second period of Expt 2, which may be due to lower densities of nauplii and rotifers in that period, increasing the proportion of veligers in the prey field. The Manly's alpha index revealed selection on varying prey items depending on availability. Although high selection indices were found on copepods other than E. affinis, the contribution in biomass of the latter to the diet of $M$. stenolepis was dominant and therefore far more important as an energy source. In the absence of copepodites, highest predation rates were found on E. affinis nauplii. These results are supported by the foraging pattern found by stomach analysis of $M$. stenolepis in a previous study in the ETZ of the St. Lawrence River (Winkler et al. 2003). In general, M. stenolepis showed selective foraging behaviour on larger prey rather than opportunistic feeding on smaller and more abundant prey, suggesting $M$. stenolepis to be a raptorial feeder. Low selection of highly abundant veligers and rotifers suggests that $M$. stenolepis is inefficient in filter feeding on these 2 items, probably due to the morphology of mouthparts and to active avoidance of this prey. $M$. mixta has been observed to switch from small prey to bigger prey during ontogeny. Younger and smaller individuals of $M$. mixta preyed on rotifers in June and July, when rotifers were the main prey (Viherluoto \& Viitasalo 2001b), whereas at a size comparable to the size of $M$. stenolepis used in this study bigger prey were preferred. No comparable data on small $M$. stenolepis are available.

In contrast, Neomysis americana may be characterised primarily as a filter feeder preying opportunistically on the most available prey, veligers, rotifers and nauplii, confirming observations of filter feeding on nauplii by mysids (Cooper \& Goldman 1980, Aaser et al. 1995), and in accordance with models of optimal foraging behaviour described for other mysid species such as Mysis relicta (Grossnickle 1982), Praunus flexuosus (Viitasalo \& Rautio 1998, Winkler \& Greve 2004) and Mesopodopsis slabberi (Webb et al. 1987). No comparable predation rates on rotifers and veligers are available, but high predation pressure on rotifers by Neomysis intermedia was found in a shallow eutrophic lake in Japan (Hanazato 1990). Predation rates and selection on E. affinis nauplii by Neomysis integer varied between studies, and a consistent pattern has not been observed. Higher predation rates were found in experiments with comparable densities of nauplii and copepodites, when no alternate small prey was available (Aaser et al. 1995), whereas various other studies have shown negative selection of nauplii by Neomysis spp., even at high densities (Siegfried \& Kopache 1980, Murtaugh 1981, Fockedey \& Mees 1999).

The changing prey field within and among experiments revealed a great amount of plasticity in foraging patterns of both mysid species. The mysids adapted well to changes in food composition by switching prey and changing their feeding mode, a behaviour that may serve to avoid food-limiting situations (Landry 1981). Two feeding modes co-existed during the feeding experiments, but were used in different proportions. Mysis stenolepis and Neomysis americana showed an opposite switch in foraging behaviour. $M$. stenolepis changed from raptorial to filter feeding, whereas $N$. americana switched to raptorial feeding, suggesting that in both cases low densities of preferred prey in the second half of the experiments were 
responsible for switching behaviour to ensure further energy uptake. $N$. americana and $M$. stenolepis showed food-niche partitioning, likely due to the contrasting foraging strategies and the different food preferences, thus minimising inter-specific competition while exploiting all abundant food sources.

Ingestion rates were higher when Neomysis americana was feeding on copepodites compared to the gain of biomass by exploiting small prey such as nauplii, rotifers and veligers. Why then should this species not always exploit bigger prey and hence gain more energy rather than feeding at higher rates on small prey having a lower benefit? An explanation may be that even if $N$. americana could gain more energy by raptorial feeding on copepodites, there may be a trade off due to the energy loss in pursuing, catching and handling the bigger prey item (Ramcharan \& Sprules 1986, Price 1988). Further, the high proportion of copepod biomass in the diet of $N$. americana in our experiment may be overestimated due to the fact that the calculation of eaten prey (difference of prey in the initial prey concentration and those at the middle and end of the experiments, respectively) considered only intact individuals and partly eaten prey were neglected. In this context the cladoceran Bosmina longirostris seemed to be the ideal prey, bigger than veligers, rotifers and nauplii, yet smaller and with weaker escape behaviour than copepods (Grossnickle 1982). Studies on feeding behaviour of the freshwater mysid Mysis relicta demonstrated its preference for cladocerans over copepods, and Bosmina sp. was further selected over daphnids due to its smaller size (Cooper \& Goldman 1980, Bowers \& Vanderploeg 1982). Despite its low abundance in our experiments, it formed a disproportionately large portion of the diet of both mysids, and they showed high selectivity for Bosmina (Manly's alpha). These predators thus appear able to exploit efficiently the fluctuating population of $B$. longirostis (Laprise \& Dodson 1994, Winkler et al. 2005). In contrast, $M$. mixta preferred copepods to cladocerans due to stronger hydrodynamic signals generated by copepod jumps than by cladoceran movement (Mohammadian et al. 1997, Viherluoto \& Viitasalo 2001b), and Gerritsen \& Strickler (1977) also argued that fasterswimming prey increased encounter rates with the predator compared to slower prey.

\section{Food web relationships}

Mysis stenolepis had a significantly higher trophic position $\left(13.7 \% \quad \delta^{15} \mathrm{~N}\right)$ than Neomysis americana $\left(11.5 \% \delta^{15} \mathrm{~N}\right)$ in the food web due to its greater preference for copepod prey than $N$. americana, which preyed mostly on smaller prey items such as rotifers and veligers of lower trophic positions than copepods. The trophic relationships established in the present study using stable isotopes corresponded well with the detailed feeding experiments on natural zooplankton assemblages and was consistent with the results of stomach contents analysis of an earlier study (Winkler et al. 2003). However, the difference in carbon signature between $N$. americana and veligers greatly exceeds the typical trophic enrichment of $\leq 1 \%$ from food source to the consumer (Peterson \& Fry 1987). This suggests that $N$. americana in the transition zone assimilated very few veligers or that only a negligible proportion of the diet consisted of veligers compared with other prey such as the rotifer Keratella and Bosmina longirostris. These findings stand in contrast to the high predation rates on veligers observed in our feeding experiments, in which the prey field offered in the feeding experiments was collected from the transition zone. The salinity gradient along the ETZ may, however, explain to some extent the low contribution of veligers in the carbon signature of $N$. americana collected in the field. Veliger biomass drops dramatically at 6 psu relative to 0 psu (Winkler et al. 2005), so that veligers may be a trivial source of carbon at higher salinities. Furthermore, the trophic relationship between veligers and mysids revealed by stable isotope analysis should be interpreted with caution given the highly variable carbon and nitrogen isotopic signatures of veligers and the small number of replicates for this food web component.

We did not evaluate the importance of seston (dominated by non-living organic and inorganic material) in the nutrition of mysids in feeding experiments, but the carbon signature of the seston pool was far more negative (Martineau et al. 2004) than the primary consumers and secondary consumers such as mysids. Thus, the pool of suspended organic matter is unlikely to have an important role in the nutrition of mysids, in contrast to what has been reported in other studies (Lasenby \& Langford 1973, Jansen 1985, Fockedey \& Mees 1999). The ETZ consumer food web in the St. Lawrence Middle Estuary appears to be only weakly coupled with overall particulate organic matter and therefore only loosely linked to decomposer pathways (Martineau et al. 2004, Barnard et al. 2006), which is consistent with our results; the 2 mysid species were supported by the zooplankton productivity of the ETZ, which is, in turn, supported by autochthonous carbon.

\section{Consequences for the zooplankton food web in the ETZ}

Complexity in food webs is strongly dependent on the degree of omnivory that, in turn, can be a strongly 
stabilising force within a food web (Hall \& Raffaelli 1991, Fagan 1997). In the ETZ a strong trophic coupling was suggested by Winkler et al. (2003) in accordance with the revised riverine productivity model (Thorp \& Delong 2002) that emphasises the overriding importance of autochthonous carbon for supporting metazoan production. Within the longitudinally organised zooplankton community both mysid species cooccur in the food-rich estuarine assemblage that is characterised by the maximum abundance of mesozooplankton (Laprise \& Dodson 1994, Winkler et al. 2003). Gut content analysis of the 2 species suggested omnivorous foraging and potential competition for the same food resources (Winkler et al. 2003). The results indicate that co-existence of these sympatric populations may be possible by the partitioning of food resources. Differences in the individual size of both species increases over the summer months (G. Winkler unpubl. data), favouring distinct foraging preferences and further diminishing competition between Mysis stenolepis and Neomysis americana. M. stenolepis outgrows $N$. americana over the summer, which should result in a specific foraging behaviour of strong preferences and high predation rates on Eurytemora affinis, the most abundant copepod in the ETZ during summer. In contrast, the much smaller $N$. americana should prefer small and abundant prey taxa such as rotifers, veligers and nauplii, although both mysid species may show high preference for nauplii, intensifying the predation pressure on this life stage of $E$. affinis. Although Laprise \& Dodson (1994) found a negative correlation between the abundance of mysids and E. affinis, suggesting top-down control of the copepod population, Winkler et al. (2003) demonstrated that predation pressure was not sufficient to reduce prey numbers over $3.5 \mathrm{~d}$ in the same region. Rapid reproduction by $E$. affinis may avoid such control, as was observed in a brackish lake, where reproduction of an E. affinis population resisted control by $N$. integer predation (Irvine et al. 1993).

High selectivity indices of mysids for cladocerans suggest that these spatially and temporally fluctuating populations (Winkler et al. 2005) are likely to be exploited efficiently by both mysid species, even if these prey populations occur in low densities. Smaller prey such as veligers and rotifers that outnumber copepods in the zooplankton assemblage most of the summer form an important food source for Neomysis americana. Thus, predation seems to be mediated by the temporal and spatial distribution of zooplankton prey in relation to their predators. The relative importance of different prey groups changes over time due to differences in the population dynamics of prey species, so that prey-switching behaviour will ensure successful feeding of both predators. Furthermore, omnivory and flexibility in foraging behaviour enables predators to exploit efficiently dominant prey groups, which may serve to facilitate prey population maintenance, minimise food limitation and stabilise the zooplankton community in the highly dynamic ETZ.

Acknowledgements. We thank the crew members of the 'Mordax' for their help in the field. Special thanks are extended to B. Laberge, S. Roy, C. Fasulo, A. van den Eede and J.-F. Bourque for their assistance in the laboratory and field. We also thank M. Rautio and C. Barnard for helpful discussions. This research was supported by grants from the Natural Sciences and Engineering Research Council of Canada to J.J.D., W.F.V. and L.E.J. This is a contribution to the program of Québec-Océan (Groupe Interinstitutionnel de Recherches Océanographiques du Québec), formerly GIROQ.

\section{LITERATURE CITED}

Aaser H, Jeppesen E, Søndergaard M (1995) Seasonal dynamics of the mysid Neomysis integer and its predation on the copepod Eurytemora affinis in a shallow hypertrophic brackish lake. Mar Ecol Prog Ser 127:47-56

Barnard C, Martineau C, Frenette JJ, Dodson J, Vincent WF (2006) Trophic position of zebra mussel veligers and their use of dissolved organic carbon. Limnol Oceanogr 51: 1473-1484

Bowers JA, Vanderploeg HA (1982) In situ predatory behavior of Mysis relicta, Lake Michigan. Hydrobiologia 93:121-131

Cabana G, Rasmussen J (1996) Comparison of aquatic food chains using nitrogen isotopes. Proc Natl Acad Sci USA 93: 10844-10847

Cooper SD, Goldman CR (1980) Opossum shrimp (Mysis relicta) predation on zooplankton. Can J Fish Aquat Sci 37: 909-919

Dumont HJ, Van de Valde I, Dumont S (1975) The dry weight estimate of biomass in a selection of Cladocera, Copepoda and Rotifera from the plankton, periphyton and benthos of continental water. Oecologia 19:75-97

Escaravage V, Soetaert K (1993) Estimating secondary production for the brackish Westerschelde copepod population Eurytemora affinis (Poppe) combining experimental data and field observations. Cah Biol Mar 34:201-214

Fagan WF (1997) Omnivory as a stabilizing feature of natural communities. Am Nat 150:554-567

Fockedey N, Mees J (1999) Feeding of the hyperbenthic mysid Neomysis integer in the maximum turbidity zone of the Elbe, Westerschelde and Gironde estuaries. J Mar Syst 22: 207-228

France RL, Peters RH (1997) Ecosystem differences in the trophic enrichment of ${ }^{13} \mathrm{C}$ in the aquatic food web. Can $\mathrm{J}$ Fish Aquat Sci 54:1255-1258

Frenette JJ, Vincent WF, Dodson JJ, Lovejoy C (1995) Sizedependent variations in phytoplankton and protozoan community structure across the St. Lawrence River transition region. Mar Ecol Prog Ser 120:99-110

Fulton RS (1982) Predatory feeding of two marine mysids. Mar Biol 72:183-191

Gerritsen J, Strickler JR (1977) Encounter probabilities and community structure in zooplankton: a mathematical model. J Fish Res Board Can 34:73-82

Gorokhova E, Hansson S (1997) Effects of experimental conditions on the feeding rate of Mysis mixta (Crustacea, Mysidacea). Hydrobiologia 355:167-172 
Grossnickle NE (1979) Nocturnal feeding patterns of Mysis relicta in Lake Michigan based on gut content fluorescence. Limnol Oceanogr 24:777-780

Grossnickle NE (1982) Feeding habits of Mysis relicta-an overview. Hydrobiologia 93:101-107

Hall SJ, Raffaelli D (1991) Food-web patterns: lessons from a species-rich web. J Anim Biol 60:823-842

Hanazato T (1990) A comparison between predation effects on zooplankton communities by Neomysis and Chaoborus. Hydrobiologia 198:33-40

Hansson S, De Stasio BT, Gorokhova E, Mohammadian MA (2001) Ratio-dependent functional responses-tests with the zooplanktivore Mysis mixta. Mar Ecol Prog Ser 216: 181-189

Hillbricht-Ilkowska A, Stancyzkowska A (1969) The production and standing crop of planktonic larvae of Dreissena polymorpha Pall. in two Mazurian lakes. Pol Arch Hydrobiol 16:193-203

Irvine K, Moss B, Bales M, Snook D (1993) The changing ecosystem of a shallow, brackish lake, Hickling Broad, Norfolk, UK. I. Trophic relationships with special reference to the role of Neomysis integer. Freshw Biol 29:119-139

Jansen W (1985) Stellung von Neomysis integer (Leach) (Crustacea, Mysidacea) als Konsument im Nahrungsgefüge der Darß-Zingst Boddenkette (südliche Ostsee). Fisch-Forsch 23:55-59

Jerling HL, Wooldridge TH (1995) Feeding of two mysid species on plankton in a temperate South African estuary. J Exp Mar Biol Ecol 188:243-259

Johannsson OE, Leggett MF, Rudstam LG, Servos MR, Mohammadian MA, Gal G, Dermott RM, Hesslein RH (2001) Diet of Mysis relicta in Lake Ontario as revealed by stable isotope and gut content analysis. Can J Fish Aquat Sci 58:1975-1986

Johnston NT, Lasenby DC (1981) Diet and feeding of Neomysis mercedis Holmes (Crustacea, Mysidacea) from the Fraser River Estuary, British Columbia. Can J Zool 60:813-823

Krebs (2001) Ecology: the experimental analysis of distribution and abundance, 5th edn. Benjamin Cummings, San Francisco, CA

Landry MR (1981) Switching between herbivory and carnivory by the planktonic marine copepod Calanus pacificus. Mar Biol 65:77-82

Langeland A (1988) Decreased zooplankton density in a mountain lake resulting from predation by recently introduced Mysis relicta. Verh Int Verein Limnol 23:419-429

Laprise R, Dodson JJ (1994) Environmental variability as a factor controlling spatial patterns in distribution and species diversity of zooplankton in the St. Lawrence estuary. Mar Ecol Prog Ser 107:67-81

Lasenby DC, Langford RR (1973) Feeding and assimilation of Mysis relicta. Limnol Oceanogr 18:280-285

Martineau C, Vincent WF, Frenette JJ, Dodson JJ (2004) Primary consumers and particulate organic matter: isotopic evidence of strong selectivity in the estuarine transition zone. Limnol Oceanogr 49:1679-1686

Mauchline J (1980) The biology of mysids and euphausids (Crustacea, Mysidacea). Adv Mar Biol 18:3-317

Minigawa M, Wada E (1984) Stepwise enrichment of ${ }^{15} \mathrm{~N}$ along food chains: further evidence and the relation between $\delta^{15} \mathrm{~N}$ and animal age. Geochim Cosmochim Acta 48:1135-1140

Mohammadian MA, Hansson S, De Stasio BT (1997) Are marine planktonic invertebrates food limited? The functional response of Mysis mixta (Crustacea, Mysidacea) in the Baltic Sea. Mar Ecol Prog Ser 150:113-119

Morgan MD (1981) Abundance, life history, and growth of introduced populations of the opossum shrimp (Mysis relicta) in sub alpine California lakes. Can J Fish Aquat Sci 38:989-993

Murtaugh PA (1981) Selective predation by Neomysis mercedis in Lake Washington. Limnol Oceanogr 26:445-453

Pennington JT, Hadfield MG (1989) A simple nontoxic method for the decalcification of living invertebrate larvae. J Exp Mar Biol Ecol 130:1-7

Peterson BJ, Fry B (1987) Stable isotopes in ecosystem studies. Annu Rev Ecol Syst 18:293-320

Price HJ (1988) Feeding mechanisms in marine and freshwater zooplankton. Bull Mar Sci 43:327-343

Ramcharan CW, Sprules GW (1986) Visual predation in Mysis relicta Loven. Limnol Oceanogr 31:414-420

Siegfried CA, Kopache ME (1980) Feeding of Neomysis mercedis (Holmes). Biol Bull (Woods Hole) 159:193-205

Smith EP, Zaret TM (1982) Bias in estimating niche overlap. Ecology 63:1248-1253

Sprung M (1993) The other life: an account of present knowledge of the larval phase of Dreissena polymorpha. In: Nalepa T, Schloesser D (eds) Zebra mussels: biology, impacts, and control. Lewis Publishers, Ann Arbor, MI, p 39-54

Tattersall WM, Tattersall OS (1951) The British Mysidacea. Ray Society, London

Thorp JH, Delong MD (2002) Dominance of autochthonous autotrophic carbon in food webs of heterotrophic rivers. Oikos 96:543-550

Viherluoto M, Viitasalo M (2001a) Effect of light on the feeding rates of pelagic and littoral mysid shrimps: a trade-off between feeding success and predation avoidance. J Exp Mar Biol Ecol 261:237-244

Viherluoto M, Viitasalo M (2001b) Temporal variability in functional responses and prey selectivity of the pelagic mysid, Mysis mixta, in natural prey assemblages. Mar Biol 138: 575-583

Viherluoto M, Kuosa H, Flinkman J, Viitasalo M (2000) Food utilisation of pelagic mysids, Mysis mixta and M. relicta, during their growing season in the northern Baltic Sea. Mar Biol 136:553-559

Viitasalo M, Rautio M (1998) Zooplanktivory by Praunus flexuosus (Crustacea: Mysidacea): functional responses and prey selection in relation to prey escape responses. Mar Ecol Prog Ser 174:77-87

Vincent WF, Dodson JJ, Bertrand N, Frenette JJ (1996) Photosynthetic and bacterial production gradients in a larval fish nursery: the St. Lawrence River transition zone. Mar Ecol Prog Ser 139:227-238

Wallace RK, Ramsey JS (1983) Reliability in measuring diet overlap. Can J Fish Aquat Sci 40:347-351

Webb P, Perissinotto R, Wooldridge TH (1987) Feeding of Mesopodopsis slabberi (Crustacea, Mysidacea) on naturally occurring phytoplankton. Mar Ecol Prog Ser 38:115-123

Winkler G, Greve W (2004) Trophodynamics of two interacting species of estuarine mysids, Praunus flexuosus and Neomysis integer, and their predation on the calanoid copepod Eurytemora affinis. J Exp Mar Biol Ecol 308:127-146

Winkler G, Dodson JJ, Bertrand N, Thivierge D, Vincent WF (2003) Trophic coupling across the St. Lawrence River estuarine transition zone. Mar Ecol Prog Ser 251:59-73

Winkler G, Sirois P, Johnson LE, Dodson JJ (2005) Invasion of an estuarine transition zone by Dreissena polymorpha veligers had no detectable effect on zooplankton community structure. Can J Fish Aquat Sci 62:578-592

Wooldridge TH, Webb P (1988) Predator-prey interactions between two species of estuarine mysid shrimps. Mar Ecol Prog Ser 50:21-28

Zar JH (1996) Biostatistical analysis. Prentice Hall, Upper Saddle River, NJ

Submitted: December 23, 2005; Accepted: June 19, 2006

Proofs received from author(s): February 13, 2007 